\title{
EFEKTIFITAS PLATFORM ZOOM TERHADAP HASIL BELAJAR MATA KULIAH PERSAMAAN DIFFERENSIAL BIASA SELAMA PANDEMI COVID-19
}

\author{
Iesyah Rodliyah $^{1}$, Nihayatus Sa'adah ${ }^{2}$ \\ ${ }^{1,2}$ Program Studi Pendidikan Matematika, Universitas Hasyim Asy’ari Tebuireng Jombang \\ Email: iesyahrodliyah90@gmail.com
}

\begin{abstract}
Abstrak:
Selama pandemi covid-19 pembelajaran yang semula offline dialihkan menjadi pembelajaran secara online berdasarkan kebijakan dari pemerintah untuk meminimalisir penularan wabah virus covid-19. Sehingga hal ini memberikan dampak pada hasil belajar para peserta didik khususnya mahasiswa. Salah satu aplikasi yang mendukung pembelajaran online adalah platform zoom. Tujuan penelitian ini adalah untuk mengetahui keefektifan penggunaan platform zoom terhadap hasil belajar mahasiswa yang mengampu mata kuliah persamaan differensial biasa. Penelitian ini merupakan penelitian eksperimen yang menggunakan metode kuantitatif. Populasinya merupakan seluruh mahasiswa prodi pendidikan matematika di Universitas Hasyim Asy'ari dengan sampel 19 mahasiswa yang mengampu mata kuliah persamaan differensial biasa. Teknik pengumpulan data menggunakan metode tes dan juga angket. Teknik analisis data yang digunakan adalah uji normalitas dan juga uji hipotesis menggunakan uji-t untuk mengetahui keefektifan platform zoom terhadap hasil belajar. Selain itu, hasil angket respon para mahasiswa dianalisis menggunakan persentase hitung berdasarkan hasil rata-rata. Berdasarkan analisis data yang sudah dilaksanakan, diperoleh kesimpulan bahwa penggunaan platform zoom selama pelaksanaan perkuliahan mata kuliah persamaan differensial biasa efektif digunakan untuk meningkatkan hasil belajar mahasiswa, selain itu para mahasiswa memberikan respon positif terhadap penggunaan platform zoom selama perkuliahan berlangsung.
\end{abstract}

Kata Kunci: Efektifitas, Platform Zoom, Persamaan Differensial Biasa, Hasil Belajar

\begin{abstract}
:
During the COVID-19 pandemic, learning that was originally offline was shifted to online learning based on government policies to minimize the transmission of the COVID-19 virus outbreak. So that this has an impact on the learning outcomes of students, especially students. One application that supports online learning is the zoom platform. The purpose of this study was to determine the effectiveness of using the zoom platform on student learning outcomes who teach ordinary differential equations courses. This research is an experimental research that uses quantitative methods. The population is all students of the mathematics education study program at Hasyim Asy'ari University with a sample of 19 students who teach ordinary differential equations courses. Data collection techniques using the test method and also a questionnaire. The data analysis technique used is the normality test and also the hypothesis test using the t-test to determine the effectiveness of the zoom platform on learning outcomes. In addition, the results of the questionnaire responses of the students were analyzed using a calculated percentage based on the average result. Based on the data analysis that has been carried out, it is concluded that the use of the zoom platform during the implementation of the ordinary differential equation course is effectively used to improve student learning outcomes, in addition, the students gave a positive response to the use of the zoom platform during the lecture.
\end{abstract}

Keywords: Effectiveness, Zoom Platform, Common Differential Equations, Learning Outcomes

\section{Pendahuluan}

Pada akhir tahun 2019, Dunia sedang dihadapkan dengan pandemi Covid19 atau yang lebih dikenal dengan Corona
Virus Desease-2019. COVID-19 adalah pandemi terbesar dalam sejarah modern (Gloster, dkk, 2020). Kasus ini berawal dari Negara China tepatnya di daerah Wuhan. 
Kemudian virus corona mulai mewabah di Indonesia sekitar awal maret 2020. Wabah pandemi COVID-19 telah mempengaruhi sistem kesehatan secara global (Favas, Fysal, \& Naveen, 2020). Penyebaran virus yang semakin hari semakin meningkat membuat pemerintah segera mengeluarkan kebijakan-kebijakan dengan tujuan memutus rantai penularan Covid-19. Salah satunya dengan melakukan social distancing yaitu tindakan dimana setiap individu dengan individu yang lain dilarang saling berdekatan (Setiani, 2020). Adapun kebijakan lainnya yang telah dikeluarkan oleh pemerintah sangat berdampak pada berbagai bidang. Salah satunya bidang pendidikan. Virus corona mempengaruhi sistem pendidikan di dunia. Mulai dari sekolah sampai perguruan tinggi ditutup untuk mengendalikan penyebaran virus corona (Tadesse \& Muluye, 2020).

Kebijakan yang sudah mulai diterapkan oleh pemerintah di Indonesia adalah dengan dilaksanakannya PSBB (Pembatasan Sosial Berskala Besar). Setiap menteri pun turut memberikan kebijakan yang memperoleh persetujuan dari pemerintah, termasuk menteri pendidikan dan kebudayaan. Sesuai dengan edaran yang telah dikeluarkan oleh Menteri Pendidikan dan Kebudayaan Nomor 3 tahun 2020. Maka telah ditetapkan pelaksanaan home learning atau yang lebih dikenal dengan istilah School From Home. (Rodliyah, dkk. 2020 : 115)

Kebijakan School from home menyebabkan pembelajaran mulai dari sekolah tingkat dasar sampai perguruan tinggi mulai beralih dari yang semula offline menjadi pembelajaran online atau lebih dikenal dengan istilah PJJ (Pembelajaran Jarak Jauh). Pembelajaran jarak jauh ini merupakan suatu pola pembelajaran yang berlangsung dengan adanya keterpisahan antara para pendidik dengan peserta didik dengan memanfaatkan sumber belajar berbasis teknologi, komunikasi, dan media yang lain (Ismawati $\&$ Prasetyo, 2021). Efektifitas pembelajaran jarak jauh ini bertumpu pada kemampuan dan keterampilan para pendidik ketika menyampaikan materi pengajaran sebagaimana pembelajaran dilakukan secara tatap muka (Zulfikar, 2020). Pembelajaran jarak jauh adalah alternatif yang baik ketika pembelajaran di kelas dihentikan selama masa pandemi COVID19 (Sutiah, dkk, 2020). Pendidikan jarak jauh dikenal juga dengan istilah e-learning. E-Learning merupakan aplikasi yang dibuat untuk mengatasi keterbatasan dalam hal ruang dan waktu antara para pendidik dan peserta didik (Monica \& Fitriawati, 2020). Selain itu, dengan menggunakan e-learning para pendidik dan peserta didik tidak harus berada dalam satu dimensi ruang dan waktu sehingga pembelajaran bisa tetap berjalan dengan mengabaikan dua hal tersebut (Sukirno, 2021).

Di era revolusi industri 4.0 saat ini terdapat banyak berbagai platform digital yang bisa dimanfaatkan sebagai penunjang keterlaksanaan pembelajaran jarak jauh, diantaranya Platform Zoom, Google Meet, Edmodo, V-Class, Skype, Youtube Live, Webwx, Whatsapp, dan masih banyak berbagai aplikasi yang lain (Kelana, Wulandari, \& Wardani, 2021). Platform pendidikan yang berbeda telah digunakan oleh para pendidik untuk memfasilitasi pengaturan pembelajaran jarak jauh (Bautista, dkk, 2021). Berikut ini adalah daftar platform yang sering dipakai di Indonesia berdasarkan Arus Survei Indonesia dalam Kumparan.com 2020 (Nalurita, 2021) :

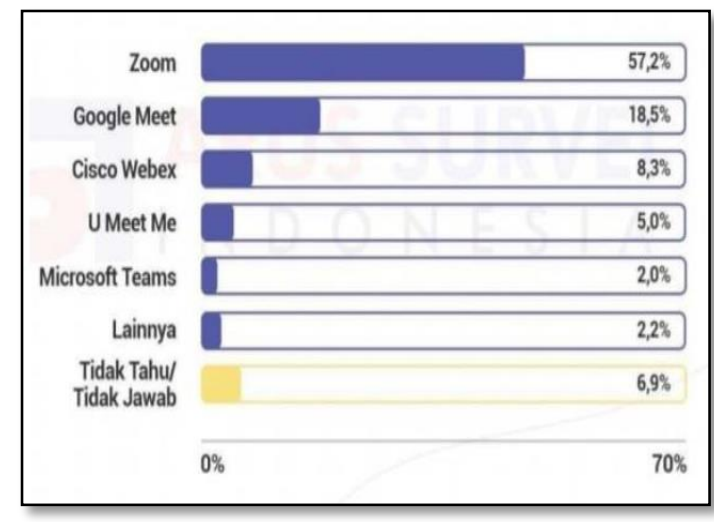

Gambar 1. Daftar platform yang sering dipakai di Indonesia

Hasil survei menunjukkan bahwa platform zoom menduduki peringkat pertama sebagai aplikasi yang paling sering digunakan oleh masyarakat Indonesia dalam pembelajaran daring. Platform Zoom 
merupakan aplikasi yang didirikan oleh Eric Yuan yang diresmikan pada tahun 2011. Aplikasi ini banyak dimanfaatkan sebagai suatu media pembelajaran yang menggunakan video, bukan hanya itu platform ini juga sering digunakan untuk urusan perkantoran maupun bisnis (Haqien \& Rahman, 2020).

Selama pandemi covid-19 pembelajaran online menggunakan aplikasi zoom menjadi alternatif para pendidik khususnya para guru dan dosen untuk menyampaikan materi pembelajaran kepada para peserta didik. Tidak sedikit para peneliti yang telah melakukan penelitian terkait penggunaan aplikasi zoom, diantaranya penelitian yang dilakukan oleh Kasman \& Hamdani (2020) dengan judul "The Effect Of Zoom App Towards Students' Interest In Learning On Online Learning." Hasil penelitian ini menunjukkan adanya peningkatan minat belajar siswa dengan menggunakan aplikasi zoom sebagai modalitas belajar di masa pandemi. Penggunaannya terbukti berpengaruh signifikan terhadap semangat belajar siswa sehingga terjadi peningkatan minat belajar siswa. Selanjutnya penelitian yang dilakukan oleh Putra (2020) dengan judul "Solusi Pembelajaran Jarak Jauh Menggunakan Aplikasi Zoom dan Whatsapp Group di Era New Normal Pada Warga Belajar Paket C Di Pusat Kegiatan Belajar Masyarakat (PKBM) Bina Insani." Hasil penelitian menunjukkan bahwa aplikasi Zoom dan Whatsapp Group memfasilitasi beberapa setting pembelajaran diantaranya asinkron mandiri, asinkron kolaboratif, dan sinkron maya. Selain itu, aplikasi Zoom juga memfasilitasi fitur forum diskusi. Penelitian berikutnya dilakukan oleh Sholihin (2020) dengan judul "Pembelajaran Online dengan Aplikasi Zoom Meeting di Kelas 5 SDN 1 Selaawi di Masa Pandemi Covid-19." Hasil penelitian menunjukkan bahwa aplikasi zoom mampu membuat siswa merasakan tidak adanya perbedaan antara pembelajaran online dengan pembelajaran tatap muka secara langsung di kelas.

Berbagai kelebihan penggunaan aplikasi platform zoom sudah banyak diterapkan dan dirasakan oleh para pengguna dalam pembelajaran daring. Oleh karena itu, pada penelitian ini peneliti juga tertarik untuk membahas keefektifan aplikasi platform zoom terhadap hasil belajar mahasiswa pada mata kuliah persamaan differensial biasa. Mata kuliah persamaan differensial biasa merupakan mata kuliah yang membekali mahasiswa dengan pengetahuan, pemahaman, tentang klasifikasi persamaan differensial, latar belakang munculnya persamaan differensial, persamaan differensial biasa ordo satu, persamaan differensial linear orde dua, pemetaan laplace beserta pemetaan inversnya, dan penggunaan persamaan differensial biasa pada kehidupan sehari-hari. Perkuliahan persamaan differensial biasa yang biasanya dilakukan secara tatap muka harus beralih dengan perkuliahan jarak jauh dengan memanfaatkan aplikasi zoom. Hal ini merupakan tantangan baru bagi para dosen untuk mengemas materi yang diberikan agar bisa sebaik sebagaimana pembelajaran secara tatap muka. Dengan adanya aplikasi zoom ini diharapkan pembelajaran online yang dilaksanakan tetap efektif terhadap hasil belajar mahasiswa pada mata kuliah persamaan differensial biasa sebagaimana pembelajaran dilakukan secara offline dengan berinteraksi secara langsung di kelas.

\section{Metode Penelitian}

Penelitian ini merupakan penelitian eksperimen yang menggunakan metode kuantitatif. Hal ini dikarenakan kriteria keefektifan yang digunakan dalam penggunaan aplikasi zoom pada penelitian ini dilihat dari hasil belajar mahasiswa yaitu pretest dan postest serta hasil angket respon mahasiswa. Populasi yang digunakan adalah seluruh mahasiswa pendidikan matematika di Universitas Hasyim Asy'ari dengan sampel sebanyak 19 mahasiswa yang mengampu mata kuliah persamaan differensial biasa. Instrumen penelitian terdiri dari Soal Pretest dan Posttest, serta Angket Respon Mahasiswa. 
Teknik pengumpulan data menggunakan metode tes dan juga angket. Sedangkan untuk teknik analisis data hasil tes mahasiswa menggunakan uji normalitas dan uji hipotesis, untuk data berupa angket akan dilakukan analisis angket respon mahasiswa sebagaimana akan diuraikan berikut ini :

\section{Analisis Uji Normalitas}

Adapun langkah-langkah uji normalitas yang digunakan adalah sebagai berikut (Rustam, 2016 : 57-58) :

1. Data hasil pengamatan disusun mulai dari nilai pengamatan terkecil sampai nilai pengamatan terbesar

2. Dari nilai pengamatan tersebut, kemudian disusun, distribusi frekuensi kumulatif relative yang dinotasikan dengan $\mathrm{Fa}(\mathrm{Y})=\frac{f k}{n}$

3. Menghitung nilai $Z y$ dengan rumus $: Z$ $=\frac{Y-\bar{Y}_{1}}{S}$, dengan $\bar{Y}=$ rata-rata dan $\mathrm{S}=$ Standar Deviasi

4. Menghitung distribusi frekuensi kumulatif teoritis atau frekuensi harapan yang dinotasikan dengan $\mathrm{Fe}$ $(\mathrm{Y})$. Fe (Y) dilihat dari tabel kurva normal.

5. Menentukan nilai mutlak dari selisih $\mathrm{Fa}(\mathrm{Y})$ dan $\mathrm{Fe}(\mathrm{Y})$ yang dinotasikan dengan D

6. Membandingkan nilai Dmaks dengan nilai Dtabel dimana : Dmaks $=$ maks $|\mathrm{Fa}(\mathrm{Y})-\mathrm{Fe}(\mathrm{Y})|$ dengan $\alpha=0,05$. Dtabel $=\mathrm{D}(0,05 ; \mathrm{n})$ dengan $\mathrm{n}$ adalah banyaknya sampel penelitian.

Kriteria Pengujian adalah sebagai berikut :

- Jika $D_{\text {maks }} \leq D_{\text {tabel. }}$ maka Ho diterima artinya data yang dikumpulkan berdistribusi normal

- Jika $D_{\text {maks }}>D_{\text {tabel. }}$ maka Ho ditolak artinya data yang dikumpulkan tidak berdistribusi normal

\section{Analisis Uji Hipotesis}

Jika data yang digunakan merupakan data normal. Maka selanjutnya bisa dilakukan pengujian hipotesis menggunakan uji-t.
1. Ho : Penggunaan Platform Zoom tidak efektif terhadap hasil belajar mahasiswa pada mata kuliah persamaan differensial biasa

2. H1 : Penggunaan Platform Zoom efektif terhadap hasil belajar mahasiswa pada mata kuliah persamaan differensial biasa

3. $\alpha=0,05$

4. Kriteria Penolakan Ho : Tolak $H_{0}$ jika : $t>t_{\frac{\alpha}{2} ; v}$

5. Menghitung nilai $t$ :

Mean Different $(\bar{D}) \rightarrow \bar{D}=\frac{\sum_{i=1}^{n} D_{i}}{n}$

Simpangan Baku $\left(\boldsymbol{S}_{\boldsymbol{D}}\right) \rightarrow$

$$
S_{D}=\sqrt{\frac{n \sum_{i=1}^{n} D_{i}^{2}-\left(\sum_{i=1}^{n} D_{i}\right)^{2}}{n(n-1)}}
$$

Statistik untuk menguji $H_{0} \rightarrow \quad \boldsymbol{t}=\frac{\bar{D}-\mu_{0}}{\frac{\boldsymbol{S}_{\boldsymbol{D}}}{\sqrt{n}}}$ dengan derajat bebas t adalah $: v=n-1$ 6. Menarik Kesimpulan (Walpole, 1995 : 305)

\section{Analisis Hasil Respon Mahasiswa}

Analisis data respon mahasiswa dianalisis menggunakan rumus sebagai berikut :

$$
\text { Persentase }(\%)=\frac{\sum f}{N} \times 100 \%
$$

Dengan $\sum f$ : Jumlah Jawaban Responden

$$
\mathrm{P} \text { : Persentase Respon }
$$

Tabel 1. Kriteria Penskoran Menurut Skala Likert

\begin{tabular}{cc}
\hline Nilai (\%) & Kriteria \\
\hline Sangat Setuju & 4 \\
Setuju & 3 \\
Tidak Setuju & 2 \\
Sangat Tidak Setuju & 1 \\
\hline
\end{tabular}

Tabel 2. Kriteria Interpretasi Skor Berdasarkan Interval

\begin{tabular}{cc}
\hline Nilai $(\%)$ & Kriteria \\
\hline $0 \%-19.99 \%$ & Sangat Kurang \\
& Baik \\
$20 \%-39.99 \%$ & Kuang Baik \\
$40 \%-59.99 \%$ & Cukup baik \\
$60 \%-79.99 \%$ & Baik \\
$80 \%-100 \%$ & Sangat Baik \\
\hline & (Pratiwi, 2021)
\end{tabular}

(Pratiwi, 2021) 


\section{Hasil dan Pembahasan Hasil}

Data yang diperoleh dari metode tes yaitu hasil pretest dan posttest mahasiswa setelah mengikuti perkuliahan persamaan differensial biasa menggunakan aplikasi zoom kemudian dianalisis dengan uji normalitas terlebih dahulu sebelum dilakukan uji hipotesis.

Tabel 3. Hasil Pretest dan Posttest

\begin{tabular}{|c|c|c|c|}
\hline No. & Mahasiswa & Pretest & Posttest \\
\hline 1. & $M_{1}$ & 30 & 90 \\
\hline 2. & $M_{2}$ & 20 & 92 \\
\hline 3. & $M_{3}$ & 30 & 86 \\
\hline 4. & $M_{4}$ & 25 & 84 \\
\hline 5. & $M_{5}$ & 20 & 87 \\
\hline 6. & $M_{6}$ & 15 & 74 \\
\hline 7. & $M_{7}$ & 15 & 86 \\
\hline 8. & $M_{8}$ & 25 & 86 \\
\hline 9. & $M_{9}$ & 40 & 86 \\
\hline 10. & $M_{10}$ & 30 & 88 \\
\hline 11. & $M_{11}$ & 25 & 84 \\
\hline 12. & $M_{12}$ & 15 & 75 \\
\hline 13. & $M_{13}$ & 25 & 84 \\
\hline 14. & $M_{14}$ & 35 & 86 \\
\hline 15. & $M_{15}$ & 40 & 92 \\
\hline 16. & $M_{16}$ & 25 & 84 \\
\hline 17. & $M_{17}$ & 15 & 88 \\
\hline 18. & $M_{18}$ & 20 & 76 \\
\hline 19. & $M_{19}$ & 25 & 88 \\
\hline & ata-Rata & 25 & 85.05263 \\
\hline Sta & lar Deviasi & 7.81736 & 5.082363 \\
\hline
\end{tabular}

Dari hasil perhitungan uji normalitas untuk data pretest diperoleh hasil $D_{\text {tabel }}=D_{(0.05 ; n)}=D_{(0.05 ; 19)}=0.301$. Sedangkan $D_{\text {Maks }}=0.1842$. Karena $D_{\text {maks }}<D_{\text {tabel }}$ maka Ho diterima artinya data yang dikumpulkan berdistribusi normal. Sedangkan hasil perhitungan uji normalitas untuk data posttest diperoleh hasil $D_{\text {tabel }}=D_{(0.05 ; n)}=D_{(0.05 ; 19)}=0.301$. Sedangkan $D_{\text {Maks }}=0.1231$. Karena $D_{\text {maks }}<D_{\text {tabel. }}$ maka Ho diterima artinya data yang dikumpulkan berdistribusi normal.

Data yang sudah dilakukan uji normalitas dan diperoleh hasil bahwa data berdistribusi normal. Maka langkah selanjutnya dilakukan uji hipotesis menggunakan analisis uji-t. Berdasarkan hasil analisis statistik yang telah dilakukan diperoleh nilai $t_{\text {hitung }}=37,545$. Selanjutnya nilai $t_{\text {hitung }}$ dibandingkan dengan nilai $t_{\text {tabel }}$ dengan derajat kebebasan $(v)=18$ dan taraf signifikan $(\alpha)$ sebesar 5\%. Maka nilai dari $t_{\text {tabel }}=$ $t_{0.025 ; 18}=2.101$. Dengan melihat kriteria penolakan $H_{0}$ maka dapat disimpulkan bahwasanya penggunaan platform zoom efektif terhadap hasil belajar mahasiswa pada mata kuliah persamaan differensial biasa.

Selesai melaksanakan perkuliahan persamaan differensial biasa, mahasiswa diharuskan mengisi angket yang sudah disediakan untuk memberikan respon terhadap penggunaan platform zoom selama perkuliahan berlangsung. Berdasarkan hasil angket respon yang sudah diberikan oleh mahasiswa diperoleh hasil berikut :

\section{Tabel 4. Hasil Angket Respon Mahasiswa}

\begin{tabular}{|c|c|c|c|c|}
\hline \multirow{2}{*}{ Pernyataan } & \multicolumn{4}{|c|}{ Frekuensi } \\
\hline & 4 & 3 & 2 & 1 \\
\hline $\begin{array}{l}\text { Proses pembelajaran } \\
\text { daring menggunakan } \\
\text { aplikasi zoom adalah } \\
\text { hal baru bagi saya }\end{array}$ & 18 & 1 & & \\
\hline $\begin{array}{l}\text { Saya merasa senang } \\
\text { mengikuti perkuliahan } \\
\text { PDB menggunakan } \\
\text { aplikasi zoom }\end{array}$ & 17 & 2 & & \\
\hline $\begin{array}{l}\text { Pengoperasian aplikasi } \\
\text { zoom sangat mudah } \\
\text { bagi saya }\end{array}$ & 17 & 1 & 1 & \\
\hline $\begin{array}{l}\text { Perkuliahan PDB } \\
\text { menggunakan aplikasi } \\
\text { zoom dapat } \\
\text { meningkatkan } \\
\text { motivasi belajar saya } \\
\text { dalam proses } \\
\text { pembelajaran daring }\end{array}$ & 16 & 3 & & \\
\hline $\begin{array}{l}\text { Pembelajaran } \\
\text { menggunakan aplikasi } \\
\text { zoom menurut saya } \\
\text { menarik } \\
\text { menyenangkan }\end{array}$ & 15 & 4 & & \\
\hline
\end{tabular}


Penyampaian materi perkuliahan pada mata kuliah PDB menggunakan aplikasi zoom mempermudah saya dalam memahami materi

Proses pembelajaran daring menggunakan aplikasi zoom dapat menghilangkan rasa bosan

Penggunaan aplikasi zoom mampu mengemas pembelajaran menjadi lebih variatif dan inovatif

Penyampaian materi melalui aplikasi zoom membuat saya menjadi lebih aktif dalam mengikuti perkuliahan PDB

Penyampaian materi melalui aplikasi zoom membuat saya lebih mudah bertanya dan menyampaikan

pendapat

Penggunaan aplikasi

zoom efektif

digunakan untuk

proses pembelajaran

daring pada semua

mata kuliah khususnya

PDB

Penggunaan aplikasi

zoom mampu

membantu

memperlancar proses

pembelajaran secara

daring

Penyampaian materi

mata kuliah PDB

melalui aplikasi zoom

dapat meningkatkan

hasil belajar saya

Saya puas dengan penggunaan aplikasi

zoom dalam

membantu proses

pembelajaran secara

daring

\begin{tabular}{lcccc} 
Total & 233 & 32 & 1 & \\
Persentase (\%) & 87.6 & 12 & 0.4 & 0 \\
\hline
\end{tabular}

154

Dilihat dari tabel 4 diperoleh kesimpulan bahwasanya para mahasiswa memberikan respon positif dengan persentase sebesar 87.6\%. Artinya berdasarkan kriteria interpretasi, hasil respon mahasiswa dapat dikategorikan sangat baik.

\section{Pembahasan}

Penggunaan platform zoom merupakan salah satu solusi dalam proses pembelajaran daring selama wabah covid19. Berdasarkan hasil penelitian, adanya platform ini efektif terhadap hasil belajar mahasiswa khususnya pada mata kuliah persamaan differensial. Selain itu, mahasiswa juga memberikan respon positif yang artinya para mahasiswa juga turut merasakan kebermanfaatan aplikasi zoom selama proses perkuliahan. Pernyataan ini juga didukung oleh hasil penelitian yang telah dilakukan oleh Firmansyah (2021) yang menjelaskan bahwasanya pembelajaran online menggunakan aplikasi zoom sudah efektif. Selain itu, penggunaan aplikasi zoom juga mendapat tanggapan sangat baik dari mahasiswa karena pembelajaran yang lebih fleksibel ketika menggunakannya. Hasil penelitian Arahman (2020) juga menunjukan bahwasanya ada pengaruh yang signifikan terhadap pembelajaran online menggunakan aplikasi zoom pada mata kuliah statistik.

Berikut ini adalah beberapa dokumentasi kegiatan selama perkuliahan persamaan differensial biasa secara daring menggunakan aplikasi zoom :

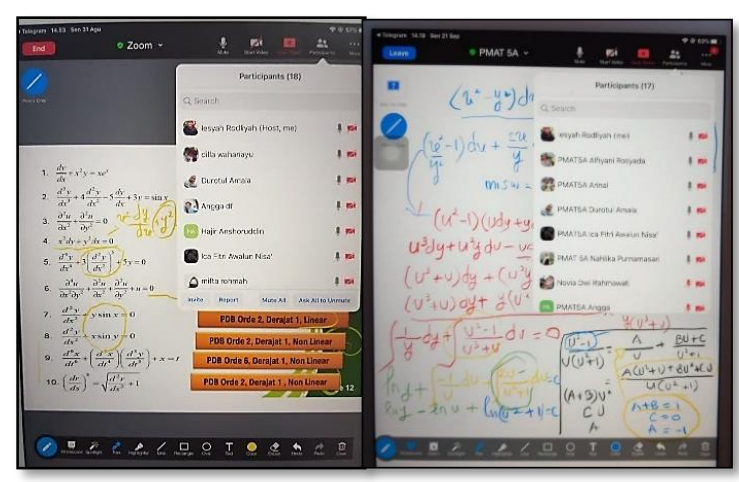

\section{Gambar 2. Aktifitas Selama Perkuliahan Persamaan Differensial Biasa}

Selama memanfaatkan aplikasi platform zoom, peneliti juga memanfaatkan 
microsoft power point dibantu dengan apple pencil untuk menjelaskan setiap materi ketika menyampaikan materi persamaan differensial biasa. Perangkat ini sangat mendukung memaksimalkan perkuliahan secara daring menggunakan zoom. Hal ini menjadikan para mahasiswa juga lebih merasakan bahwa perkuliahan daring yang dilaksanakan hampir tidak ada bedanya dengan perkuliahan secara tatap muka. Pratama, dkk (2020) menjelaskan bahwa penggunaan aplikasi meeting online seperti zoom ini sangat membantu dalam proses belajar mengajar. Secara keseluruhan terdapat trend yang meningkat dan berpengaruh terhadap penggunaan aplikasi pertemuan secara online dalam menyelesaikan pembelajaran masalah di masa depan.

Berbagai kelebihan platform zoom yang sudah dipaparkan ternyata masih memiliki beberapa kekurangan. Hal ini bisa dilihat dari hasil angket respon mahasiswa, bahwa sebanyak $0.4 \%$ yang menyatakan bahwasanya pengoperasian zoom masih dirasa sulit. Dengan alasan koneksi jaringan yang tersedia di daerah tempat tinggal mahasiswa tersebut masih tergolong rendah sehingga terkadang masih sangat sulit untuk mengoperasikan zoom. Terkendalanya mengakses zoom juga dirasakan jika kuota internet habis. Permasalahan ini juga didukung oleh pernyataan dari Ganesha, dkk (2021) yang menyebutkan bahwasanya penerapan pembelajaran online melalui aplikasi zoom di SD Karya Mekar berhasil dilaksanakan, dengan siswa yang sangat antusias melakukan pembelajaran online melalui Zoom Meeting. Namun pembelajaran online tidak semudah belajar seperti biasanya atau pembelajaran offline. Kendala yang dihadapi oleh para siswa selama pembelajaran online adalah media elektronik dan kuota internet untuk pembelajaran online. Tidak semua siswa sama dalam hal ekonomi, yang merupakan satu-satunya masalah. Far Far (2020) juga menambahkan bahwasanya Perkuliahan yang dilakukan memanfaatkan aplikasi zoom dinilai kurang efektif karena sering terkendala oleh ketersediaan jaringan/ sinyal internet bagi mahasiswa yang tidak menggunakan wifi dan akan berdampak terhadap kualitas pembelajaran yang sedang berlangsung. Namun kelebihan pemanfaatan aplikasi zoom ini dinilai praktis dan efisien bagi mahasiswa, karena dengan menggunakan platform zoom komunikasi antara mahasiswa dan dosen lebih mudah dibandingkan berkomunikasi secara tertulis atau melalui pesan singkat (chat).

\section{Simpulan dan Saran Simpulan}

Berdasarkan hasil penelitian dan pembahasan dapat disimpulkan bahwasanya pembelajaran daring menggunakan platform zoom efektif terhadap hasil belajar mahasiswa yang mengampu mata kuliah persamaan differensial biasa. Hal ini bisa dilihat dari hasil uji hipotesis yang menunjukkan bahwa $t_{\text {hitung }}=37.545>$ $t_{0.025 ; 18}=2.101$ yang berarti $H_{0}$ ditolak dan $H_{1}$ diterima. Artinya dalam hal ini dapat dikatakan bahwa penggunaan platform zoom efektif terhadap hasil belajar mahasiswa pada mata kuliah persamaan differensial biasa. Selain itu respon mahasiswa terhadap platform zoom berada pada kategori sangat baik dengan persentase sebesar $87.6 \%$.

\section{Saran}

Penelitian ini bisa dijadikan referensi untuk melakukan penelitian selanjutnya dengan menambahkan penggunaan aplikasi penunjang selama penggunaan platform zoom untuk memaksimalkan pembelajaran daring. Dengan begitu, kelemahan/kekurangan yang ada ketika melaksanakan pembelajaran melalui platform zoom bisa disempurnakan dengan adanya perangkat tambahan yang lain. Selain itu, pengambilan sampel yang lebih banyak sangat disarankan agar mampu memberikan hasil yang lebih representatif.

\section{Daftar Pustaka}

Arahman, E. (2020). The Effect of Online Learning Using Zoom on Undergraduate Students' Ability to Understand Mathematical Concepts. (IJLI) International 
Journal of Learning and Instruction Volume 2 Number 2 October 2020

Bautista, A.P., Bleza, D.G., Buhain, C.B., \& Balibrea, D.M. (2021). School Support Received and the Challenges Encountered in Distance Learning Education by Filipino Teachers during the Covid19 Pandemic. International Journal of Learning, Teaching and Educational Research. Vol. 20, No. 6, pp. 360-385, June 2021

Dr. Favas K., Dr. Fysal N. \& Dr. Naveen, K. (2021). COVID-19 infection in children: A case series. International Journal of Current Research, 13, (07), 18210-1821

Far-Far, G. (2020). Efektifitas Penggunaan Aplikasi Zoom Meeting Dalam Pembelajaran Di Masa Pandemi Covid-19. ISTORIA: Jurnal Pendidikan dan Sejarah Volume 17, No 1, September 2020

Firmansyah. (2021). Efektivitas Penggunaan Aplikasi Zoom Sebagai Media Pembelajaran Online masa Pandemi Covid-19 pada Mahasiswa STAI Al-Amin Dompu. Jurnal Studi Pendidikan Islam Vo. IX No. 2 edisi September 2020- Februari 2021

Ganesha, P., Nandiyanto, A.B.D., \& Razon, B.C. (2021). Application of Online Learning during the Covid-19 Pandemic through Zoom Meeting at Elementary School. Indonesian Journal of Teaching in Science 1 (1) (2021) 1-8

Gloster, A.T., Lamnisos, D., Lubenko, J., Presti, G., Squatrito, V., Constantinou, M., et al. (2020) Impact of COVID-19 pandemic on mental health: An international study. PLOS ONE 15(12): e0244809

Ismawati, D., \& Prasetyo, I. (2021). Efektivitas Pembelajaran
Menggunakan Video Zoom Cloud Meeting pada Anak Usia Dini Era Pandemi Covid-19. Jurnal Obsesi : Jurnal Pendidikan Anak Usia Dini, 5(1) 2021. DOI: 10.31004/obsesi.v5i1.671

Haqien, D., \& Rahman, A.A. (2020). Pemanfaatan Zoom Meeting Untuk Proses Pembelajaran Pada Masa Pandemi Covid-19. SAP (Susunan Artikel Pendidikan) Vol. 5 No. 1 Agustus 2020

Kasman, K., \& Hamdani, Z. (2021). The Effect Of Zoom App Towards Students' Interest In Learning On Online Learning. Dinasti International Journal of Education Management And Social Science, 2(3), 404-408. https://doi.org/10.31933/dijemss.v2i3 .752

Kelana, J.B., Wulandari, M.A., \& Wardani, D.S. (2021). Penggunaan Aplikasi Zoom Meeting Di Masa Pandemi Covid-19 Pada Pembelajaran Sains. Jurnal Elementary Kajian Teori dan Hasil Penelitian Pendidikan Sekolah Dasar Vol. 4 No. 1 Januari 2021, hal. 18-22.

Monica, J., \& Firiawati, D. (2020). Efektivitas Penggunaan Aplikasi Zoom Sebagai Media Pembelajaran Online Pada Mahasiswa Saat Pandemi Covid-19. Jurnal Communio : Jurnal Ilmu Komunikasi, Volume IX, No. 2, JuliDesember 2020, hlm 1630 - 1640

Nalurita, S. (2021). Pemanfaatan Aplikasi Google Meet Pada Mata Kuliah Teknik Proyeksi Bisnis Semester Gasal Tahun Pelajaran 2020/2021 Di Universitas Dirgantara Marsekal Suryadarma (Unsurya). Jurnal Ilmiah Manajemen Surya Pasca Scientia Volume 10 Nomor 1, Januari 2021

Pratama, H., Azman, M. N. A., Kassymova, G. K., \& Duisenbayeva, S. S. (2020). 
The Trend in Using Online Meeting Applications for Learning During the Period of Pandemic COVID-19: A Literature Review. Journal of Innovation in Educational and Cultural Research, 1(2), 58-68

Pratiwi, D.E. (2021). Penggunaan Aplikasi Zoom Meeting dan XLC (Xaverius Learning Center) Selama Study From Home Pada Masa Pandemi Covid-19 Di SD Katolik Xaverius Surabaya. Bina Gogik Volume 8 No. 1 Maret 2021, 37-45

Putra, N.P. (2020). Solusi Pembelajaran Jarak Jauh Menggunakan Aplikasi Zoom Dan Whatsapp Group Di Era New Normal Pada Warga Belajar Paket C Di Pusat Kegiatan Belajar Masyarakat $(\mathrm{Pkbm})$ Bina Insani. JIPSINDO, No.2, Vol.7, September 2020

Rodliyah, I., dkk. (2020). Masa-Masa Covid-19 Menuju Pendidikan di Era 5.0. Banten : CV. AA. Rizky

Rustam, A. (2016). Dasar-Dasar Statistik. Kolaka : Putri Yolanda

Setiani, A. (2020). Efektivitas Proses Belajar Aplikasi Zoom di Masa Pandemi dan Setelah Pandemi Covid-19. Prosiding Seminar Nasional Pascasarjana UNNES
Solihin, A. (2020). Pembelajaran Online dengan Aplikasi Zoom Meeting di Kelas 5 SDN 1 Selaawi di Masa Pandemi Covid-19. Gunahumas Jurnal Kehumasan Vol 3, No 2, 2020, 17-24

Sukirno. (2021). Analisis Pembelajaran Daring Dengan Menggunakan Aplikasi Zoom Bagi Mahasiswa Pada Masa Pandemi Covid-19. Best Journal Vol.4 No.1 Hal. 01-08 Februari 2021

Sutiah, S., Slamet, S., Shafqat, A., \& Supriyono, S. (2020). Implementation of distance learning during the covid-19 pandemic in faculty of education and teacher training. Cypriot Journal of Educational Sciences, 15(5), 12041214

Tadesse, S., \& Muluye, W. (2020). The Impact of COVID-19 Pandemic on Education System in Developing Countries: A Review. Open Journal of Social Sciences, 2020, 8, 159-170

Walpole, R. E. (1995). Pengantar Statistika. Jakarta : PT Gramedia Pustaka Utama

Zulfikar. (2020). Efektifitas Penggunaan Media Zoom Terhadap Pembelajaran Pada Masa Pandemi Covid-19. Jurnal Ilmiah Pranata Edu Volume 2 No.1, December 2020 